\title{
RESPONSE OF PLANT AND ARANEAE COMMUNITIES TO FOREST RESTORATION ON RECLAIMED MINE LAND ${ }^{1}$
}

\begin{abstract}
Craig Malone ${ }^{2}$, Rebecca Swab, and Alexys Nolan.
Abstract: During post surface mining for coal in the 1940s-1960s in the Appalachian region, much of the land was returned to forest either through reclamation or through natural succession. While these forests successfully established in many places, even decades later the understories often lack native understory species, and instead are dominated by invasives. There is also anecdotal evidence of a lack of regeneration of the canopy tree species. This study was conducted to evaluate the success of restoration efforts focused on understory improvement on forested reclaimed mine land in Southeast Ohio specifically focusing on Araneae and plant populations. Three different treatments were studied: managed forest with invasive species removal, managed forest with invasive species removal and subsequent native plantings, and forest that was unmanaged as a control. The first growing season after treatments, Daubenmire vegetation surveys and Rapid Upland Forest Assessments (RUFAs) were used to observe plant percent cover, species richness, Shannon-Wiener diversity, and forest health metrics among treatments. Web misting and pitfall trapping were used to observe the number of Araneae species as well as overall abundance. Plant species richness and diversity was greatest in the managed forest plots where natives were planted, followed by the managed forest plots where only invasives were removed, and lowest in the unmanaged forest where no restoration work occurred. Native plant cover in the understory and RUFA scores, an indicator of forest health, did not significantly differ between the managed and unmanaged forest. Araneae abundance and species richness were greater in the unmanaged forest. Findings indicate that invasive species removal and native plantings can have a positive impact on vegetation communities within 6-12 months after implementation. However, continued monitoring is necessary to assess the long-term impacts of these restoration techniques on vegetation communities. Further research should be conducted on Araneae communities to observe how populations change over time and if understory structure has an effect on these communities.
\end{abstract}

Additional Key words: Invasive species; Spider; Vegetation

1. Paper submitted to JASMR for consideration. Published by ASMR, 1305 Weathervane Dr., Champaign, IL 61821.

2. Craig Malone, Restoration Ecology Apprentice, The Wilds, Cumberland, $\mathrm{OH}$ 43732; Rebecca M. Swab, Director of Restoration Ecology; Alexys Nolan, Restoration Ecology Program Associate, The Wilds.

DOI: http://dx.doi.org/10.21000/JASMR19030048 


\section{$\underline{\text { Introduction }}$}

Since 1930, over six million acres of land have been disturbed by surface coal mining in the Appalachian United States (Skousen et al., 2009). Surface mining causes loss of natural ecosystems, as well as deterioration of soil integrity. Prior to the Surface Mining Control and Reclamation Act (SMCRA) of 1977, most mine lands were replanted with trees during reclamation or afterwards (Rodrigue, 2001; Zipper et al., 2011). Post-SMCRA soil erosion and acid mine drainage issues decreased as a result of new regulations, but the difficulty of forest reestablishment in compacted soil led reclamationists to seed grasslands instead (Zipper et al., 2011). Due to these factors, restoration ecologists have been struggling to find a practical way to reforest this landscape (Skousen et al., 2009; Zipper et al., 2011).

Many of the pre-SMCRA forests successfully established into healthy, productive tree communities (Rodrigue and Burger, 2001), some with good potential for timber 20 to 55 years after planting (Rodrigue et al., 2002). However, these forests frequently had lower plant species diversity than unmined areas, and were often dominated by conifers (Rodrigue et al., 2002). In addition, these forests included abundant invasive species such as tree of heaven (Ailanthus altissima), multiflora rose (Rosa multiflora), and autumn olive (Elaeagnus umbellata) due to low soil nutrients and lack of competition typical of highly disturbed landscapes transitioning into forests (Wade et al. 1985; Burke et al. 2016). On reclaimed mine lands, these exotic pioneer species were often planted due to their quick growth, tolerance to low $\mathrm{N}$ and $\mathrm{P}$ soils, and lower cost compared to native species (Wade et al., 1985). The further spread of species such as $E$. umbellata after planting reduces ecological integrity of forest ecosystems (Gratton and Denno, 2005). Invasive shrubs tend to overshadow and outcompete understory species and canopy species seedlings by preventing their growth and establishment, especially on reclaimed mine land where native seed banks may have been completely or severely depleted. Gratton and Denno (2005) have demonstrated that removal of invasive plant species can lead to restoration of both plant and arthropod assemblages to previous native states, however this may be more

problematic on reclaimed mine land. Without control, the rapid growth and expansion of these invasive species has dominated forest understories and suppressed overall forest health on previously mined lands. 
Forests provide ecosystem services such as timber production and carbon sequestration, and mitigate global climate change. Restoration of forest biomes provides environmental benefits to both humans and wildlife, as well as economic benefits for humans (Birdsey, 1992). There is a need to restore and manage reclaimed mine land forests, and to determine the best methods for these practices. Even in unmined ecosystems, it has been shown that removal of invading plants without planting native vegetation increases the chance of reinvasion, as well as removing cover/food for native fauna (Zavaleta et al., 2001). This is likely to be even more true of reclaimed mine lands, which often have high abundances of invasives to reinvade and small (if any) native seed banks. Much of forest restoration focuses on planting trees, with the assumption that understory vegetation will follow; however, research has shown that planting native species is necessary to increase abundance of native understory species (McClain et al., 2011). Native understory plants contribute more than $80 \%$ of overall species richness in some forests (Gillam, 2007), and provide food and shelter for birds, mammals, and insects (Golet et al., 2008). Given the immense soil disturbance and lack of native seedbank in reclaimed forests, as well as the importance of native understory species, native species plantings after invasive species removal may be necessary to restore reclaimed forests to a healthier, more sustainable condition.

This study evaluated methods for restoring reclaimed forests by comparing plant and spider biodiversity in two differently managed areas and in an unmanaged control forest on reclaimed mine land. Vegetation surveys, mostly of vascular plants, have been used as a basic analysis for studying "the ecological state" in different ecosystems (Clausen, 1986). Forest health and integrity relies on many factors such as floral diversity, native species composition, and unbroken food chains. While there is no strong correlation between spiders (Araneae) and vegetation species composition, spider abundance, survival, and reproduction tends to be associated with factors such as food abundance, moisture, and temperature (Clausen, 1986). The relationship between Araneae populations and these environmental factors means that Araneae can be used to monitor conditions of a forest biome that will affect the biodiversity of other invertebrates with similar conditional restrictions (Neet, 1996). Indicator species that are susceptible to modest environmental changes, such as Araneae, can be a good marker of overall ecosystem health beyond diversity of vegetation. 
Like herbaceous understory plants, different Araneae species have different habitat requirements (Clausen, 1986). Vegetation structure characteristics, leaf litter abundance, and soil nutrient levels can all have an impact on which Araneae species will be present (Neet, 1996). Araneae community composition can show the effects of different management methods on understory invertebrate communities. In a situation where clearcutting has occurred, it would be expected that web spinning species such as orb weavers would decrease, while ground hunting spiders increase, ultimately impacting invertebrate prey populations by decreasing the number of ground dwelling insects in the ecosystem (Coyle, 1981). This unbalance in the food web observed by Coyle (1981) can negatively affect forest health by decreasing prey populations for

other predators and decreasing overall species diversity. Araneae are also good pest control in newly establishing understories. Under favorable conditions, spiders can act as a "stabilizing agent" and regulate invertebrate populations in forest ecosystems (Nyffeler and Benz, 1987). Monitoring Araneae populations will grant insight into the overall health of invertebrate populations in the understory of forests.

This paper aims to describe species diversity and richness of plants and Araneae across three treatment areas, all in forested area which was previously surface mined for coal: managed forests where invasive species were removed and natives planted, managed forest where only invasive species were removed, and an unmanaged forest as a control where no invasives were removed.

\section{$\underline{\text { Methods }}$}

\section{$\underline{\text { Location }}$}

This project took place in an upland forest on reclaimed mine lands on The Wilds' property. The Wilds is a nearly 10,000 acres conservation center located in southeastern Ohio (39.8 N, $81.7 \mathrm{~W})$. Prior to coal surface mining between the 1940s and 1970s the site was forested, and during reclamation in the 1960s-1972 large portions of The Wilds, including the study area, were replanted to forest. These reclaimed forests typically have low species diversity, are dominated by invasive shrubs, and lack native understory vegetation. In the study area prior to restoration efforts, the most abundant canopy species were honey locust (Gleditsia triacanthos), sycamore (Platanus occidentalis), and black cherry (Prunus serotina), and the most common understory species were autumn olive (Elaeagnus umbellata) and multiflora rose (Rosa multiflora). Soil analysis results from March 6, 2018 in 6 points within the area found soil properties to vary 
somewhat between points, with $\mathrm{pH}$ levels ranging from 7.1-7.7, $\mathrm{P}$ 12-42 lbs/ac, $\mathrm{K}$ 0.30.6meq/100g, Mg 3.5-5.1 meq/100g, and Ca 17.1-30.3 meq/100g.

Restoration efforts in the forest began in 2017, with removal of invasive vegetation using a mix of mechanical methods (chainsaws, hand clippers) and herbicide (dabbing stumps after cutting and spraying invasive shrub re-sprouts with triclopyr solutions). Cut stems were piled into brush piles for wildlife habitat. Invasive removal in the 10 acres occurred over the course of the year, and by spring 2018 the entire area was clear. Within the invasive removal area (managed forest), 12 plots 0.13 ha in size were created to test two different treatments; six of these had native planting after invasive removal, while the other six had invasives removed but no native species planted (Fig. 1). After planting, the entire area was revisited again and follow up invasive species removal occurred, primarily through re-spraying re-sprouts. For comparison, control plots were placed in a nearby unmanaged forest where no invasive species removal or native planting took place. All vegetation and Araneae sampling took place between June and August 2018.
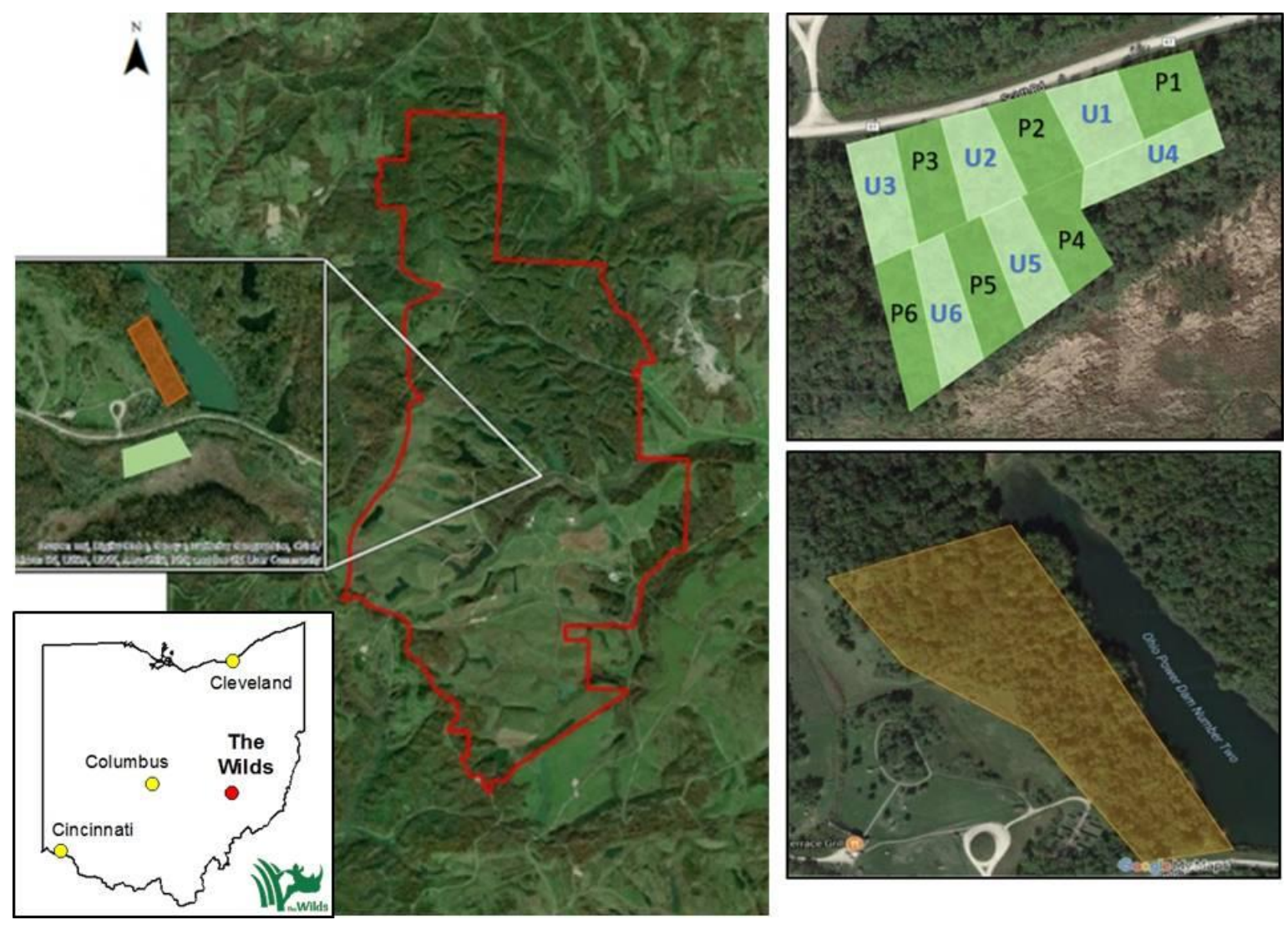
Figure 1. Left: Outline of The Wilds in Cumberland, Ohio and location of study site within the property. Right: Enlarged view of the unmanaged forest (orange) and the managed forest (green); U1 through U6 were unplanted while P1 through P6 were planted.

Planting occurred between March and April, 2018. Seeds were spread on March $1^{\text {st }}$ and $9^{\text {th }}$, 2018, including a mix of 16 herbaceous, native, shade tolerant species such as heart leaved aster (Symphyotrichum cordifolium) and white snakeroot (Ageratina altissima).

On April 21st, 2018, 514 herbaceous plugs (Species listed in Table 1) were planted with dibble bars and trowels in clusters of 4-5 individuals, spaced throughout the plots. On April $14^{\text {th }}$ and $21^{\text {st }}$, a total of 288 understory and 360 canopy bareroot seedlings were planted with dibble bars (Species listed in Table 1). An equal number of individuals were planted in each plot with somewhat random placement, but with at least 6' distance from existing trees and between seedlings. Native understory shrubs were selected through Maximum entropy modeling using MaxEnt to determine which species had projections of suitable climate at the location in 70 years given climate projections from WorldClim.

Table 1. List of woody shrub, herbaceous plugs, and trees planted in the HFHW experimental plots between March-April 2018. Trees and shrubs were planted as bareroot seedlings. 
Journal American Society of Mining and Reclamation, 2019 Vol.8, No.3

\begin{tabular}{|c|c|c|c|}
\hline SPECIES & COMMON NAME & DENSITY (PLANTS/PLOT) & TOTAL NUMBER OF PLANTS \\
\hline \multicolumn{4}{|l|}{ WOODY SHRUB SPECIES } \\
\hline CERCIS CANADENSIS & Redbud & 12 & 72 \\
\hline CORNUS RACEMOSA & Gray Dogwood & 12 & 72 \\
\hline VIBURNUM DENTATUM & Arrow-Wood & 12 & 72 \\
\hline VIBURNUM PRUNIFOLIUM & Black Haw & 12 & 72 \\
\hline WOODY SHRUB TOTAL & & 48 & 288 \\
\hline \multicolumn{4}{|l|}{ HERBACEOUS SPECIES } \\
\hline AQUILEGIA CANADENSIS & Wild Columbine & 12 & 72 \\
\hline ARISAEMA TRIPHYLLUM & Jack in the Pulpit & 21 & 126 \\
\hline MAIANTHEMUM RACEMOSUM & False Solomons seal & 25 & 150 \\
\hline EUPATORIUM PURPUREUM & Sweet Joe Pye Weed & 16 & 96 \\
\hline PHLOX DIVARICATA & Wild Blue Phlox & 20 & 120 \\
\hline HERBACEOUS TOTAL & & 94 & 564 \\
\hline \multicolumn{4}{|l|}{ TREES } \\
\hline QUERCUS RUBRA & Red Oak & 12 & 72 \\
\hline QUERCUS VELUTINA & Black Oak & 12 & 72 \\
\hline QUERCUS ALBA & White Oak & 10 & 60 \\
\hline DIOSPYROS VIRGINIANA & Persimmon & 12 & 72 \\
\hline LIRIODENDRON TULIPIFERA & Yellow Poplar & 12 & 72 \\
\hline TREE TOTAL & & 58 & 348 \\
\hline TOTAL (ALL) & & 200 & 1200 \\
\hline
\end{tabular}

\section{$\underline{\text { Plant Community Surveys }}$}

Rapid Upland Forest Assessment (RUFA). Rapid upland forest assessments (RUFA) were proposed by Burke et al. (2016) to be a universal guide to studying forest health, including factors such as invasive and native species presence. This method of evaluation provides a simple tool to assess land management outcomes and compare between sites and treatments. We have briefly described the protocol here; a more detailed description can be found in Burke et al. (2016). From the center of each 0.13 ha plot, 3 transects were run by walking for one minute in the North, Southeast, and Southwest directions. Along each transect, surveyors walked the transect repeatedly, evaluating 16 criteria including presence of large tree species, presence of standing snags, and absence of invasive species. For each criterion that adds to overall forest health, if found, a score of one was given, and if not found, a zero. A total score for each plot was calculated by adding criteria together for each transect and averaging the three scores. Scores of 0-4 are considered low integrity, 5-9 intermediate, and 10-16 high (Burke et al., 2016). 
Vegetation Surveys: Daubenmire Method. Surveys of plant cover were completed in early July 2018 to compare vegetation richness, cover, and diversity among treatments using a modified Daubenmire method (Daubenmire, 1959; Zavaleta et al., 2001). A 50m transect was positioned in the middle of each plot with a $10 \mathrm{~m}$ buffer zone at the beginning and end of the plot. A $1 \mathrm{~m}^{2}$ quadrat was placed, alternating sides, every five meters for a total of ten quadrats per transect. Within each quadrat, all plant species were identified, and percent coverage of each species was calculated. A field guide was used to identify all herbaceous species in the field (Newcomb, 1989), and those needing further identification were bagged and pressed to preserve. Our focus was observing the changes in flowering plants which would provide benefits to pollinators, so grasses and sedges, were identified only to family. Seven species, unable to be identified but totaling less than $1 \%$ of cover each, were excluded from statistical models. Raw vegetation data was used to calculate species richness, Shannon-Wiener diversity, and total percent cover of native plants among managed forest plots with natives replanted, managed forest plots without natives planted, and the unmanaged forest.

\section{Araneae Survey Methods}

Pitfall Trapping for Ground Hunting Araneae. Pitfall trapping took place from late August to mid-September of 2018. A $32 \mathrm{oz}$ plastic cup was placed into a hole dug into the ground in the center of each plot to allow. Each cup was approximately $115 \mathrm{~m}$ apart from one another to account for unintended Araneae dispersal, mostly ground hunting species as orb weavers do not travel to catch prey. To ensure that rainwater would not flood the trap, traps were placed approximately 15-20mm above the ground. A lip of soil was built around the rim of the trap container to allow invertebrates to walk into the trap. A 1" diameter wire mesh, designed to prevent the capture of the endangered American burying beetle (Nicrophorus americanus) which is released on site, was then placed flush with the surface of the trap and a polystyrene plate situated above the mesh $30 \mathrm{~mm}$ from the soil surface which was secured by wooden kebab skewers to provide shade and further protection from rain. Traps were emptied daily Tuesday through Thursday and a cover was placed over it for the weekend to prevent unwanted captures. Unknown specimens were taken back to the lab for further identification under a microscope. Araneae were identified with the use of the Ohio Division of Wildlife field guide to the lowest taxonomic unit possible (Bradley, 2012). To categorize the species caught, the guild system was used to separate spider species into orb weavers and ground hunters. 
Web Misting. In order to survey Orb Weavers, mister bottles were used to find their webs. Simulating mist to increase visibility of webs in a forest does not alarm the spider and allows identification as the spider stays on the now visible web (Tolbert, 1976). Each 0.13 ha plot was divided into eight equal sized squares (approximately 15x15 meters), and two were chosen with a random number generator to determine where to mist. Misting was carried out with a spray bottle for a total of two minutes per square by walking up and down the plot, spraying constantly from ground level to about 8'. Spiders were counted for abundance and also identified to species to assess diversity and species richness (Table 2). All unknown spiders were taken back to the lab for identification under a microscope.

Table 2: List of Araneae Species from Pitfall Trapping and Web Misting.

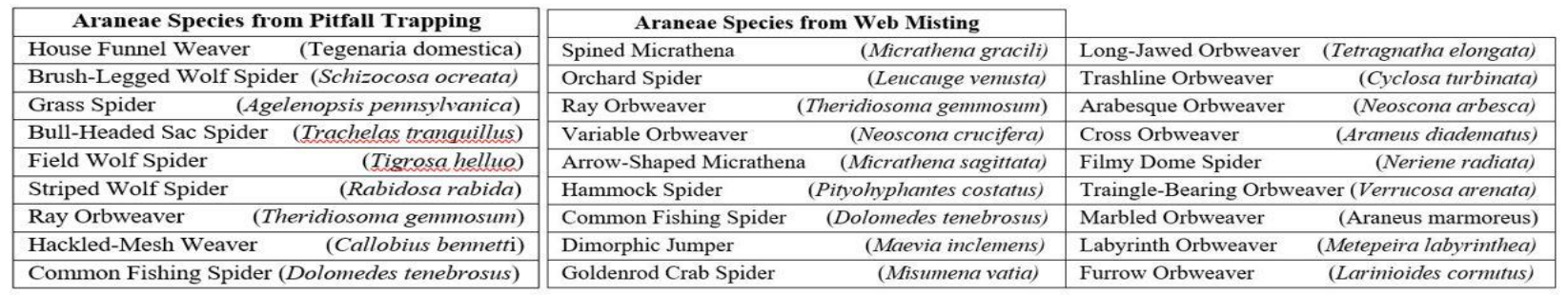

\section{$\underline{\text { Statistical Analysis }}$}

All data analysis was completed using RStudio (RStudio v2.5-2, 2018).

Rapid Upland Forest Assessment (RUFA). Three RUFA transects were conducted at each plot, and a total score out of 16 was given. RUFAs were averaged by treatment type. A KruskalWallis test with Dunn test post-hoc was run to test for significance between treatments at the $\alpha=0.05$ level.

Vegetation Surveys. Species richness, species diversity, and native plant percent coverage were calculated from vegetation survey data. For each of these measures, the 9 quadrats within each plot were averaged and the 6 plots averages compared between treatments to avoid pseudo replication. For each of these metrics, one-way analysis of variance (ANOVA) tests with Tukey's post-hoc tests were run to detect and assess significant differences among treatments at the $\alpha=0.05$ level. Shannon-Wiener diversity, a measure of the abundance and evenness of a species present, was calculated using the Vegan package in RStudio (Oksanen et al., 2018). Andreas et al. (2004) was used as a reference to determine whether each species found was native or non-native. 
Pitfall Trapping and Web Misting. For Araneae, each week was considered to be one sampling unit since weeks were temporally separate and spider composition can vary throughout the growing season. Average species richness, abundances, and total abundance was found per treatment for each week. All three weeks were averaged together to determine overall averages for each plot, and ANOVAs and Tukey tests used to test for differences between treatments.

\section{$\underline{\text { Results }}$}

\section{$\underline{\text { Vegetation Surveys }}$}

$\underline{\text { RUFA Scores. }}$ RUFA scores were higher in the managed forest plots with natives planted (6.4 \pm

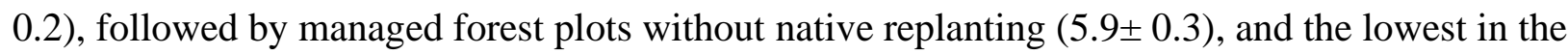
unmanaged forest plots $(5.1 \pm 0.4)$ ( $\mathrm{p}=0.04$, Fig. 2).

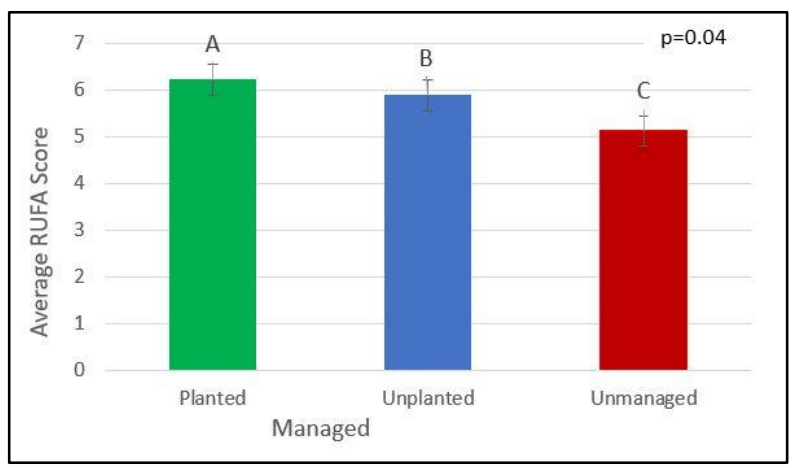

Figure 2. Average RUFA score between treatments. RUFA is a metric of forest health, with a maximum potential value of 16- higher values= higher quality forests (Burke et al., 2016)

Daubenmire surveys. Herbaceous plant species richness was highest in the managed forest plots with natives planted $(8.2 \pm 0.3)$, followed by managed forest plots without native replanting (7.7 $\pm 0.3)$, and the lowest in the unmanaged forest plots $(5.6 \pm 0.2)(\mathrm{p}<0.001$, Fig. 3). Managed forest plots with natives planted had the highest diversity $((2.4 \pm 0.2)$, followed by managed forest plots without native replanting $(2.2 \pm 0.2)$, and then the lowest was the unmanaged forest plots $(1.7 \pm 0.2)$ ( $<<0.001$, Fig. 4). Native percent cover did not vary by treatment $(91.9 \% \pm 2.0$, $91.6 \% \pm 2.0,88.5 \% \pm 2.0$, respectively, $\mathrm{p}=0.285$, Fig. 5 ). 


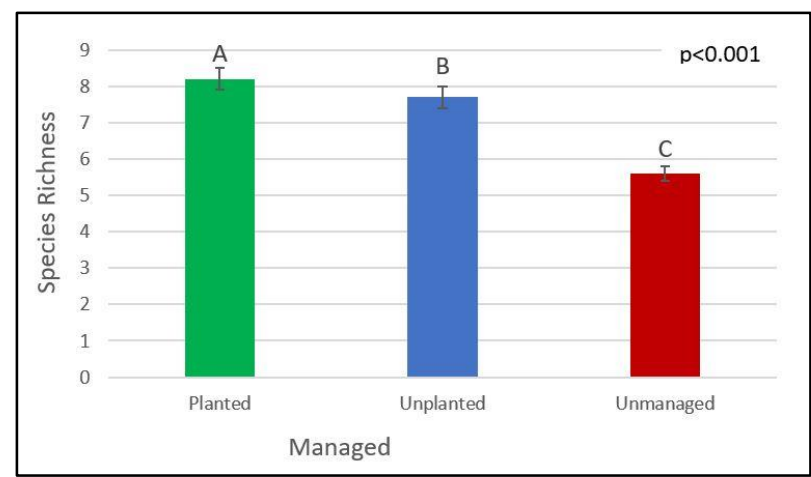

Figure 3. Average number of plant species per treatment.

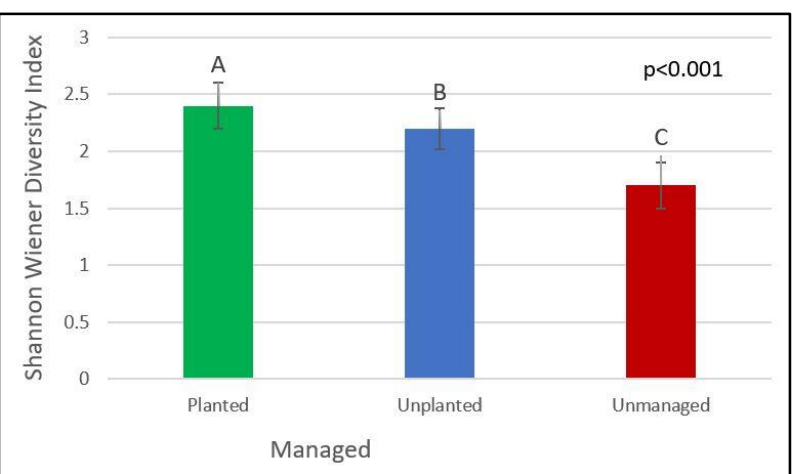

Figure 4. Shannon Weiner Diversity Index per treatment.

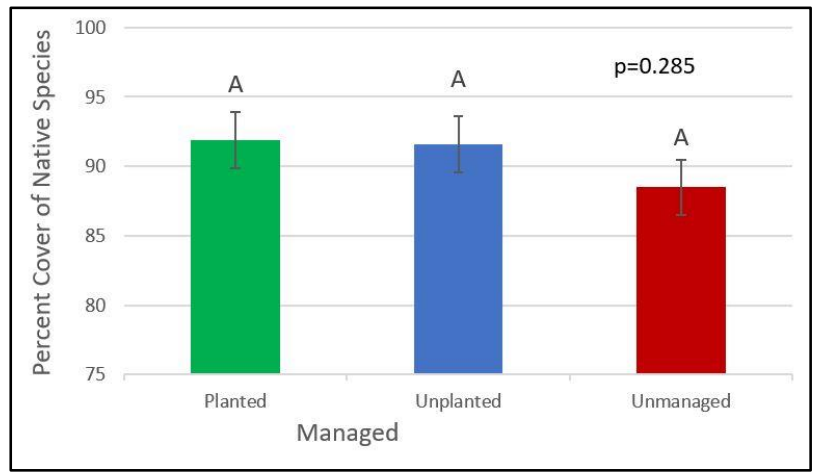

Figure 5. Average percent cover of native vegetation per treatment.

$\underline{\text { Araneae Surveys }}$

Species richness for web misting was highest in the unmanaged forest plots $(3.9 \pm 0.2)$,

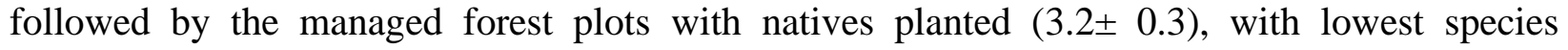
richness in the managed forest plots without native replanting (2.9 \pm 0.3$)(p=0.132$, Fig. 6). For pitfall trapping, differences were not significant, however species richness was highest in the

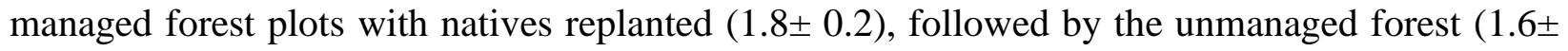
$0.1)$, and the lowest richness was in the managed forest where natives were not replanted $(0.7 \pm$ 0.2) $(\mathrm{p}=0.0589$, Fig. 6).

Araneae abundance for web misting was highest in the unmanaged forest plots (10.2 \pm 0.7$)$, followed by the managed forest plots with natives planted $(5.5 \pm 0.7)$, with lowest species richness in the managed forest plots without native replanting $(5.2 \pm 0.5)(\mathrm{p}<0.001$, Fig. 7). For pitfall trapping, the same trend was seen where the highest abundance was in the unmanaged 
forest plots $(1.3 \pm 0.3)$, then the managed forest plots with natives planted $(0.8 \pm 0.3)$, and finally

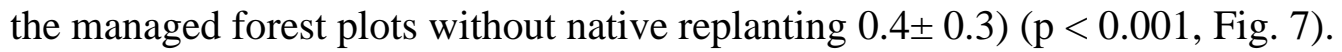

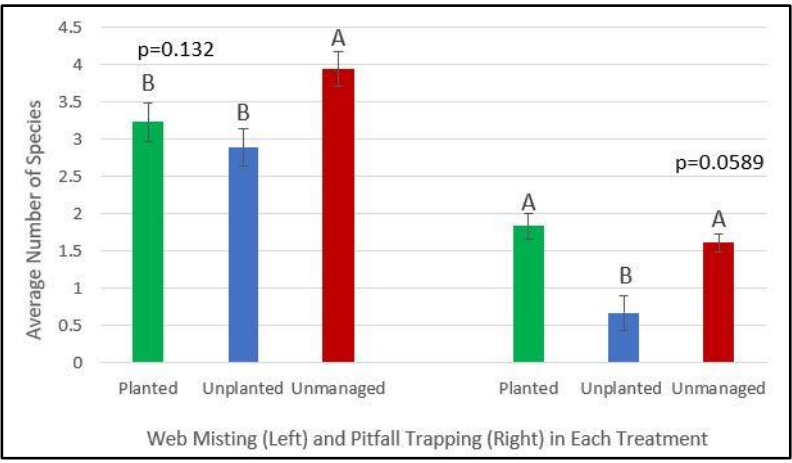

Figure 6. Mean Araneae species richness caught web misting and pitfall trapping in each treatment.

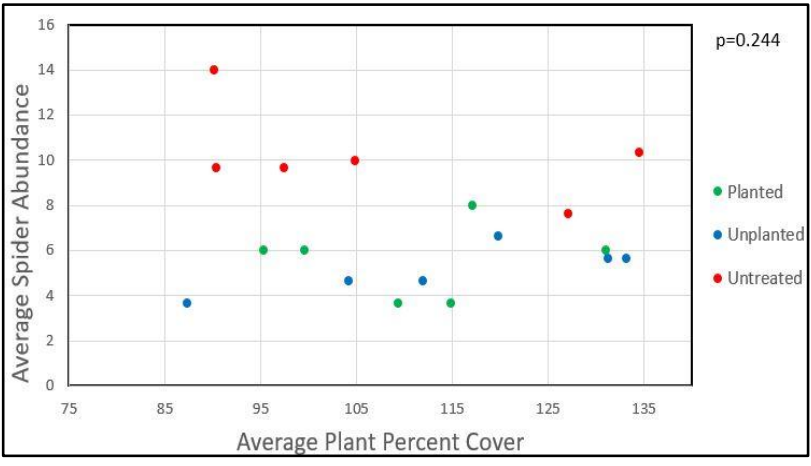

Figure 7. Regression Analysis average Araneae abundance to plant $\%$ cover in each treatment.

Araneae Abundance Vs. Plant Percent Cover. No relationship was found between Araneae abundance and plant percent cover $\left(\mathrm{r}^{2}\right.$ value $\left.=0.005\right)(\mathrm{p}=0.244)$. For example, the highest Araneae abundance (13) and the lowest abundance (4.3) were both found in plots with some of the lowest plant percentage coverage ( $89.93 \%$ and $87.3 \%$ respectively).

\section{Discussion:}

Overall results from this study show that understory plant species richness can respond quickly (within one growing season) to invasive species management and subsequent planting of native understory plants in a reclaimed forest. Spider communities may be negatively impacted by removal efforts in the short term, due to factors such as biomass removal and mechanical disruption of habitat (Thorbek and Bilde, 2004). On the contrary, vegetation diversity and richness was greater after invasive species removal. These findings are consistent with trends found by Hejda et al. (2009), where plant species richness and diversity were reduced in plots where invasive species are present. Differences in diversity were already seen between planted and unplanted plots within the managed forest, matching other results including data from years after planting (McClain et al., 2011). At this point there is no evidence of seed dispersal between plots in the managed forest, as no planted species were observed in the unplanted plots of the managed forest. However, further monitoring of this project can help determine whether seed dispersal is observed, and how it affects results. In the future, small plot sizes and dispersal may result in a convergence of plant and spider communities between the unplanted and planted plots. 
Overall, the unmanaged forest plots had few desirable, i.e., specialized understory species or rare native species, showing that the pre-SMCRA tactic of establishing trees and assuming that later successional understory species would colonize over time was unsuccessful on this reclaimed mine site at least 40 years after reforestation. Similar results have been found at other disturbed sites. A study of 15 planted riparian forests in formerly agricultural areas found understory vegetation to be dominated by early successional, exotic plant species, with native understory species diversity and species richness much lower than in remnant forests (Holl and Crone, 2004). Although our study also showed that plant species richness and diversity was significantly lower in the unmanaged forest plots than in both types of managed plots, there was no difference in native plant percent coverage between managed and unmanaged forest. This is not an uncommon result in invasive removal areas. An analysis of 89 research papers looking at native recolonization after invasive plant removal, found that $55 \%$ of these papers revealed little to no gain in native plant cover (Kettenring and Adams, 2011). This may be due to an increased abundance of other non-native species in the site, as only a few species, exclusively woody invasives, were focused on during the removal efforts. Swab et al. (2008) also found non-woody invasive species to increase abundance after honeysuckle removal, resulting in a lack of increase in native cover after invasive removal. In this case, it is likely that native species cover between treatments did not differ because the most abundant native species, false nettle (Boehmeria cylindrica) and wingstem (Verbesina alternifolia), were found in all treatments consistently. Invasive removal did increase abundance of other native individuals, but those two species dominated managed and unmanaged plots alike. While there were a higher number of quadrats containing invasive species in the unmanaged forest plots, the overall coverage was mostly dominated by false nettle and wingstem which have a high shade tolerance and thrive in all treatments. Aide et al. (2000) found similar outcomes, where nonnative species only started to decrease after long periods of reestablishment by natives. Other explanations are that the plantings failed, or that the seasonality of the species planted meant they were not present at the time of surveys. Many of the herbs planted in spring of 2018, such as Columbine (Aquilegia canadensis) and Jack in the Pulpit (Arisaema triphylium), are early season ephemerals that were not found at all during the surveys, which started in July. Management of these areas must continue for many years after the initial removal of invasive species, in order to prevent invasive 
species reestablishment; continuation of this study is also essential in order to shed some light on the management timeline.

RUFA scores, which were used to determine forest integrity, were highest in the managed forest where natives were replanted, followed by the managed forest where natives were not planted, and lowest in the unmanaged forest. Many of the characteristics scored by this integrity assessment, such as presence of large trees and presence of snags $>30 \mathrm{~cm}$, take time to improve, so it may take 10 or more years for scores to improve in managed areas. RUFA scores have been found to be significantly correlated to mature forests, early successional characteristics had a negative impact on overall forest health (Burke et al., 2016). Further studies and monitoring of these sites yearly may yield stronger results due to maturation of the forest and establishment of desirable vegetation species.

No differences were found between treatments for spider abundance or diversity despite difference in plant species richness and diversity. Web misting yielded the highest number of species observed, and had the highest species diversity in all treatments as compared to pitfall trapping. Similar methods to web misting for spider collection were found to be more effective than ground sampling when assessed in other forests (Kapoor, 2006). Web misting results showed that unmanaged forest plots, rather than managed ones, had the highest number of Araneae species present. Spider communities are prone to population decreases when crop/land is managed to the point of reducing any vegetative cover (Thorbek and Bilde, 2004), so the reductions in spider abundance here may be a result of the rapid reduction in plant material. However, when comparing spider abundance with plant percent cover, no relationship was seen. This shows that habitat factors other than plant percent cover are a primary influence on Araneae populations in this instance. It is possible that Araneae populations were affected by the changes in vegetation structure when woody invasive shrubs were removed and replaced with herbaceous species. They could also have been disturbed by the mechanical nature of the removal, which may have physically affected egg sacs (Coyle, 1981).

Overall, this previously mined forest, approximately 50 years after mining, has established an effective canopy, but the understory was dominated by exotic species. Restoration efforts in the understory of this area increased vegetation diversity and species richness, while total native plant percent cover and forest health scores were unaffected in the first year of monitoring. 
Continuation of this study will help determine whether this lack of differences was due to low sample sizes, an abundance of generalist species that could skew results, or the short time period between restoration efforts and monitoring, which may not have been an adequate establishment period for planted treatments. Through web misting and pitfall trapping, it was shown that though the unmanaged forest actually had higher abundance and species richness of Araneae, there was no relationship between Araneae and plant cover. Further research should observe Araneae patterns in both the managed and unmanaged forest. It is vital to continue monitoring native plantings and managing invasive species re-sprouts to determine whether natives are able to effectively establish and ensure that invasive species do not reemerge. Without the hands-on management to combat persistent invasive or nonnative species, native plants can be outcompeted and will not create an increase in overall forest health (McGlone et al., 2009).

\section{$\underline{\text { Acknowledgements }}$}

Wilds Apprentices and Americorps, especially Charlotte Moore and Valarie Repp. Dr. Sarah Rose, Ohio State University. Thanks to the anonymous reviewers for their suggestions. Funding sources for restoration efforts: Dominion Energy, Columbus Zoo and Aquarium, American Association of Zookeepers, The Arthur L. and Elaine Johnson Foundation, Holden Arboretum, Green Forests Work. Office of Surface Mining Reclamation and Enforcement for technical advice.

\section{$\underline{\text { Literature Cited }}$}

Aide, T.M., J.K. Zimmerman, J.B. Pascarella, L. Rivera, and H. Marcano-Vega. 2000. Forest regeneration in a chronosequence of tropical abandoned pastures: implications for restoration ecology. Restoration Ecology 8: 328-338. https://doi.org/10.1046/j.1526-100x.2000.80048.x

Andreas, B.K., J. Mack, and J. S. McCormac. 2004. Floristic quality assessment index (FQAI) for vascular plants and mosses for the State of Ohio. Ohio Environmental Protection Agency, Division of Surface Water, Wetland Ecology Group, Columbus, Ohio. 219.

Birdsey, R.A. 1992 Carbon storage and accumulation in United States forest ecosystems. U.S. Department of Agriculture, Forest Service. https://doi.org/10.5962/bhl.title.94267

Bradley, R.A. 2012 Common spiders of Ohio field guide. Ohio Division of Wildlife. https://doi.org/10.1525/california/9780520274884.001.0001 
Burke, D.J., C. Knisely, M.L. Watson, S.R. Carrino-Kyker, and R.L. Mauk. 2016. The effects of agricultural history on forest ecological integrity as determined by a rapid forest assessment method. Forest Ecology and Management 378: 1-13. https://doi.org/10.1016/j.foreco.2016.07.004

Clausen, I.H. 1986. The use of spiders (Araneae) as ecological indicators. British Arachnological Society 7: 83-86.

Coyle, F.A. 1981. Effects of clearcutting on the spider community of a Southern Appalachian forest. Journal of Arachnology 9:285-298.

Daubenmire, R. 1959. A canopy coverage method of vegetational analysis. Northwest Scientific Association 33: 43-64.

Gilliam, F.S. 2007 The ecological significance of the herbaceous layer in temperate forest ecosystems. BioScience 57: 845-858. https://doi.org/10.1641/B571007

Golet, G.H., T. Gardali, C.A. Howell, J. Hunt, R.A. Luster, W. Rainey, M.D. Roberts, J. Silveira, H. Swagerty, and N. Williams. 2008. Wildlife response to riparian restoration on the Sacramento River. San Francisco Estuary and Watershed Science 6(2).

Gratton, C. and R.F. Denno. 2005. Restoration of arthropod assemblages in a spartina salt marsh following removal of the invasive plant phragmites australis. Restoration Ecology 13: 358372. https://doi.org/10.1111/j.1526-100X.2005.00045.x

Hejda, M., P. Pysek, and V. Jarosik. 2009. Impact of invasive plants on the species richness, diversity and composition of invaded communities. Journal of Ecology 97: 393-403. https://doi.org/10.1111/j.1365-2745.2009.01480.x

Holl, K.D. and E.E. Crone. 2004. Applicability of landscape and island biogeography theory to restoration of riparian understory plants. Journal of Applied Ecology 41: 922-933. https://doi.org/10.1111/j.0021-8901.2004.00949.x

Kapoor, V. 2006. An assessment of spider sampling methods in tropical rainforest fragments of the Anamalai hills, Western Ghats, India. Zoos' Print Journal 21: 2483-2488. https://doi.org/10.11609/JoTT.ZPJ.1520.2483-8 
Kettenring, K.M. and C.R. Adams. 2011. Lessons learned from invasive plant control experiments: a systematic review and meta-analysis. Journal of Applied Ecology 48: 970-979. https://doi.org/10.1111/j.1365-2664.2011.01979.x

McClain, C.D., K.D. Holl, and D.M. Wood. 2011. Successional models as guides for restoration of riparian forest understory. Restoration Ecology 19: 280-289. https://doi.org/10.1111/j.1526100X.2009.00616.x

McGlone, C.M., J.D. Springer, and D.C. Laughlin. 2009. Can pine forest restoration promote a diverse and abundant understory and simultaneously resist nonnative invasion. Forest Ecology and Management 258: 2638-2646. https://doi.org/10.1016/i.foreco.2009.09.024

Neet, C.R. 1996. Spiders as indicator species: lessons from two case studies. Proceedings of the XIIIth Congress of Arachnology 2:501-510.

Newcomb, L. Newcomb's Wildflower Guide. Little, Brown and Company, 1989.

Nyffeler, M and G, Benz 1987. Spiders in natural pest control: A review. Journal of Applied Entomology 103: 1-5. https://doi.org/10.1111/j.1439-0418.1987.tb00992.x

Oksanen, J., F.G. Blanchet, M. Friendly, R. Kindt, P. Legendre, D. McGlinn, et al., 2018. vegan: Community Ecology Available at: https://cran.rproject.org/web/packages/vegan/index.html

Rodrigue, J.A. 2001. Woody Species Diversity, Forest and Site productivity, stumpage value, and carbon sequestration of forests on mined lands reclaimed prior to the passage of the surface mining control and reclamation act of (1977). M.S. Thesis. Virginia Tech. 315.

Rodrigue, J.A. and J.A. Burger. 2001. Forest and site productivity on preSMCRA mined land. In: Proc of the 18th Annual Meeting of the American Society for Mining and Reclamation 121130. https://doi.org/10.21000/JASMR01010121

Rodrigue, J.A., J.A. Burger, and R.G. Oderwald. 2002. Forest Productivity and Commercial Value of Pre-Law Reclaimed Mined Land in the Eastern United States. Northern Journal of Applied Forestry 19: 106-114 https://doi.org/10.1093/njaf/19.3.106

RStudio Team. 2015. RStudio: Integrated Development for R. RStudio, Inc., Boston, MA URL http://www.rstudio.com . 
Journal American Society of Mining and Reclamation, 2019 Vol.8, No.3

Skousen, J., J. Gorman, E. Pena-Yewtukhiw, J. King, J. Stewart, P. Emerson, and C. DeLong. (2009). Hardwood tree survival in heavy ground cover on reclaimed land in west Virginia: mowing and ripping effects. Journal of Environment Quality 38: 1400. https://doi.org/10.2134/jeq2008.0297

Swab, R.M., L. Zhang, and W.J Mitsch (2008). Effect of hydrologic restoration and Lonicera maackii removal on herbaceous understory vegetation in a bottomland hardwood forest.

Restoration Ecology 16: 453-463. https://doi.org/10.1111/j.1526-100X.2007.00315.x

Thorbek, P. and T. Bilde. 2004. Reduced numbers of generalist arthropod predators after crop management. Journal of Applied Ecology 41: 526-538. https://doi.org/10.1111/j.00218901.2004.00913.x

Tolbert, W.W. 1976. The use of a water sprayer in web building spider density determinations. The Journal of Arachnology 4: 211-214.

Wade, G.L., R.L. Thompson, and W.G. Vogel. 1985. Success of trees and shrubs in an 18-yearold planting on mine spoil. Res. Pap. NE-567. Broomall, PA: US Department of Agriculture, Forest Service, Northeastern Forest Experiment Station. 10: 567.

Zavaleta, E.S., R.J. Hobbs, and H.A. Mooney. 2001. Viewing invasive species removal in a whole-ecosystem context. Trends in Ecology \& Evolution 16: 454-459. https://doi.org/10.1016/S0169-5347(01)02194-2

Zipper, C.E., J.A. Burger, J.G. Skousen, P.N. Angel, C.D. Barton, V. Davis, V. and J.A. Franklin. 2011. Restoring forests and associated ecosystem services on Appalachian coal surface mines. Environmental management 47: 751-765. https://doi.org/10.1007/s00267-011-9670-z 